\title{
CONSIDERAÇÕES ACERCA DA GEOGRAFIA DE ALEXANDER VON HUMBOLDT: TEORIA, FILOSOFIA E CONCEPÇÃO DE NATUREZA
}

\section{Considerations about the geography of Alexander von Humboldt: Theory, Philosophy and Nature's concept}

\author{
Kalina SPRINGER ${ }^{1}$
}

\section{RESUMO}

Para o conhecimento em Geografia, não se pode desconsiderar a influência que o movimento romântico exerceu no contexto de sua sistematização enquanto conhecimento unificado por um corpo teórico e metodológico dotado de cientificidade. A ciência geográfica se consolida na Alemanha em meados do século XIX, com fundamentos teóricos, filosóficos e metodológicos advindos de uma hibridização entre concepções românticas e positivistas, de mundo, de ciência e de sociedade. Assim, este artigo tem como objetivo principal levar ao leitor um pouco da geografia desenvolvida por Alexander von Humboldt, reportando-se também ao contexto filosófico e histórico da época, bem como à discussão de natureza presente em seus textos.

Palavras-chave: Alexander von Humboldt; Epistemologia da Geografia.

\section{ABSTRACT}

Considering Geography, one can not ignore that the influence of the romantic movement had in the context of their systematic knowledge as a unified body of theoretical and methodological endowed scientificity. The geographical science consolidates in Germany, in the mid-nineteenth century, with theoretical foundations, philosophy and methodology derived from a hybridization between romantic and positivist conceptions of world, science and society. Therefore, this article has its as main objective to bring the reader a bit of the geography developed by Alexander von Humboldt, also referring to the philosophical and historical context of the time, and the discussion of this nature in their texts.

Keywords: Alexander von Humboldt; Geography's Epistemology. 


\section{CONTEXTUALIZAÇÃO}

A ciência geográfica enquanto conhecimento sistematizado se consolida na Alemanha em meados do século XIX; influenciada pelo romantismo (principalmente por pensadores como Schiller, Schelling, Göthe e Fichte), pelo positivismo de Bacon, Descartes, Newton; e por ideais políticos e econômicos específicos (nacionalismo, expansionismo, colonialismo, capitalismo). Pensar a ciência geográfica como um conhecimento autônomo, demandava certas condições, históricas, filosóficas, técnicas e científicas que somente naquele momento aconteceram. De acordo com Mendonça (1998), na Geografia as características deste início da produção científica refletem os princípios básicos da concepção positivista da realidade. Já para Vesentini (1989), esta ciência teria nascido a partir de interesses específicos: conhecimento de território e inculcação viam sistema escolar de uma ideologia patriótica e nacionalista que criasse um sentimento nacionalista.

Do ponto de vista filosófico, segundo Gomes (1996), a Geografia moderna teria surgido influenciada por uma dupla filiação filosófica advinda de Kant e Herder. Para o autor, Herder teve uma enorme importância para a história das ideias enquanto figura central da hermenêutica moderna e da ciência romântica. Já Safranski (2007) relaciona Herder ao Volksgeist ${ }^{2}$ presente no contexto alemão. No entanto a maioria dos geógrafos estaria de acordo em considerar que o primeiro sistema filosófico capaz de definir o valor da geografia moderna apareceu na obra de Kant. Neste contexto Vitte (2007) argumenta que:

É justamente a Terceira Crítica, com o velho Kant (1724-1804) já liberto das formulações mecanicistas da obra newtoniana, que interferirá na estruturação da Geografia moderna, a partir de reflexões sobre teologia da natureza e estética, e sob o paradigma biológico do organismo, redimensionará a questão do espaço, do tempo, do lugar e da natureza no mundo moderno. Assim a geografia moderna, nasce da relação entre a teologia da natureza e a estética moderna, como a formulada por Kant e que encontrará na Naturphilosophie e na obra de Alexander von Humboldt (1769-1859) as condições necessárias para o seu surgimento (VITTE, 2007, p. 11).

Éneste contexto queAlexander von Humboldt(1769 -1859) ${ }^{3}$, naturalista e viajante, desponta-se como sendo um dos responsáveis pela sistematização do conhecimento geográfico. Contraditório é que, na Geografia moderna brasileira, ele é pouco estudado: suas obras raramente são lidas e pouco se sabe a respeito de sua vida. Assim, este artigo tem como objetivo principal levar ao leitor um pouco da geografia desenvolvida por Alexander von Humboldt, reportando-se também ao contexto filosófico e histórico da época, bem como a discussão de natureza presente em seus textos. Como base para o desenvolvimento do artigo, tem-se quatro obras: "Os quadros da Natureza"; "Kosmos: um ensaio sobre a física do mundo" (ambas de Humboldt e com dois volumes cada), e duas biografias, escritas por Hanno Beck e Werner Feisst, após o falecimento de Humboldt, que reúnem várias informações e imagens dos trabalhos desenvolvidos por ele.

\section{ROMANTISMO}

Só agora podemos fixar a significação suprema de ritmo, harmonia e melodia. Eles são as formas primeiras e mais puras do movimento no universo e, intuídos realmente, o modo como as coisas materiais são iguais às idéias. Os corpos celestes flutuam nas asas da harmonia e do ritmo; aquilo que se chamou de força centrípeta e força centrifuga outra coisa não é senão - esta, o ritmo, aquela, a harmonia. Suspensa nessas mesmas asas, a música flutua no espaço, para tecer um universo audível a partir do corpo transparente do ruído e do som (SCHELLING, 2001, p.160).

Os antecedentes históricos e culturais do Romantismo fazem parte de um processo complexo do qual participam a evolução da Ciência e da Filosofia, o progresso econômico e social propiciado pela Revolução Industrial ao longo do século XVIII, a ascensão da classe burguesa e o desenvolvimento do modo de produção capitalista e, por fim, a Revolução Francesa, em 1789. De acordo com Pallardó (1968), durante o iluminismo, o conhecimento se processava por meio da observação direta dos fenômenos e as leis científicas tornam-se apoio indispensável e irrefutável para a explicação dos fenômenos que constituem o Universo. Para Horkheimer e Adorno (1969) com o auxílio da razão o homem desejava "escapar" da tutelagem em que por própria culpa se deixara prender ${ }^{4}$.

2 Ideologia Nacionalista.

3 Gomes (2007) ressalta que, embora a sistematização da Geografia tenha se dado com as obras de Ritter e Humboldt não se deve colocar em dúvida o papel e a importância do saber geográfico anteriormente produzido.

4 Referindo-se a Idade Média. 
SPRINGER, K. Considerações acerca da geografia de Alexander Von Humboldt...

Já no plano filosófico, o positivismo propôs explicações abrangentes do mundo, compreensão de todos os fenômenos do real, afirmação das possibilidades da razão humana e a aceitação de que o homem teria condições de superar as próprias limitações e criar um mundo perfeito. Com este raciocínio se descobriria que a Natureza dotou os homens de rigorosos e puros princípios de justiça, que segundo Hampson (1973) Ihes propiciariam o bem-comum, o progresso e o melhor dos mundos.

Neste sentido, a cosmovisão iluminista por meio do intelecto procurava explicar-se e explicar a Humanidade, racionalmente e empiricamente. Entretanto, segundo Guinsburg (1985), este período de efervescência cientifica foi marcado também por intensas manifestações cujas ideias vinham de encontro a estes postulados positivistas fundamentados por Descartes e Newton, que concebiam o mundo como uma grande máquina cujas engrenagens estariam submissas ao pensamento cartesiano.

Contudo, se de um lado a razão triunfante conseguiu idealizar um mundo perfeito e, portanto, justo. Por outro, a experiência sensível apontava para uma realidade cruel e injusta. A inatingibilidade das mudanças sociais prometidas sob o lema "liberdade, igualdade e fraternidade" criou um contexto favorável à instalação de uma "crise" no pensamento iluminista, na economia capitalista e na crença do modo de pensar racionalista. Consequentemente, propagou-se um clima de insatisfação e descontentamento alimentados de perto pela frustração e pela ânsia de liberdade. Esta "liberdade" estaria baseada em dois pontos: de um lado almejava-se a liberdade econômica e social por meio da luta política contra as estruturas sociais dominantes e do outro lado emergia a descoberta do elemento humano como um "eu" sufocado pelas estruturas sociais vigentes. Neste momento, criou-se uma conjuntura favorável à descoberta do homem enquanto individuo que, dando valor extraordinário ao seu "eu" interior e sentindo-se sufocado por uma estrutura societária deficiente e injusta, buscava alternativas de libertação daquele modelo 'doente' de sociedade.

Em meio a este contexto, no fim do século XVIII, na Alemanha, o Romantismo adquiriu contornos de doutrina. Para Safranski (2007) o romantismo não foi um fenômeno unicamente alemão, mas foi na Alemanha que encontrou um panorama cultural propício a sua eclosão e desenvolvimento. Política e socialmente a
Alemanha ${ }^{5}$ se caracterizava pela existência de vários territórios fragmentados e pela existência de múltiplos estados independentes subjugados pela influência de seus soberanos. Neste cenário, aconteceu a revolta de alguns intelectuais alemães contra este autoritarismo feudal com seus "valores convencionais" e a busca por uma identidade cultural e consciência nacionalista.

Desta forma, o romantismo na acepção aqui adotada, vai muito além de um movimento literário, sendo este considerado apenas como uma das formas sob as quais os ideais românticos se manifestaram. Safranski (2007) diferencia romantismo e romântico: romântico se refere a uma época especifica. Já o romantismo, embora tenha encontrado na época romântica as condições ideais para seu desenvolvimento, não se restringe unicamente àquele período, existe até hoje, sendo uma espécie de Geisteshaltung ${ }^{6}$. Com este mesmo pensamento, Moisés (1984) afirma que o romantismo se constitui em uma profunda e vasta revolução cultural.

Essa "revolução cultural" nasceu de uma profunda ânsia de liberdade; de um lado, por meio da luta política contra velhas estruturas que culminou com a Revolução Francesa e, de outro, por meio da libertação do ser do jugo das leis deterministas, com a descoberta de "um primeiro princípio metafísico, ação efetiva, original e universal". Este "principio metafísico" que segundo a concepção iluminista poderia se relacionar às leis do sistema absolutista e às leis físicas newtonianas, segundo Bornheim (1985) foi agora denominado e compreendido por Fichte como um "Eu" entendido como autoconsciência pura.

Assim, o homem descobriria a individualidade sustentando o princípio de que o sujeito é o centro de tudo e de que a realidade exterior não passa de uma extensão dele. Para Paz (1984) mais que um movimento literário, o romantismo foi também uma "moral", uma "erótica" e uma "política". Se não foi uma religião, foi algo mais que uma estética e uma filosofia: um modo de pensar, sentir, enamorar-se, combater, viajar; um modo de viver e um modo de morrer. Moisés (1984) escreve ainda que o romântico se deixa conduzir por uma noção relativista de Arte, por meio da qual o belo, o bem e o verdadeiro dependem da sensibilidade individual e podem, em consequência, surgir onde menos se espera, alheios a qualquer critério prévio.

No romantismo as palavras-chaves eram "sentimento", "misticismo", "anseio", "mãe-natureza" e "introversão". O que se passaria dentro do homem, no

5 O território que hoje se delimita como Alemanha.

6 Estado de espírito 
"eu", é que deveria agora ser levado em consideração no processo de aquisição de conhecimentos. Assim, segundo Guimarães (1997) o romantismo foi uma reação ao mecanicismo ${ }^{7}$, à fragmentação do homem e à ênfase ao culto frio da razão. No movimento romântico o homem não era só razão, não era um ser somente calculista: ele era um ser subjetivo, sensível, emotivo e repleto de sentimentos.

Desta forma, reporta-se a Rousseau (1712-1778) que, apesar de não provocar uma ruptura total com os princípios do racionalismo iluminista, questionou os conceitos de natureza e de homem defendidos pelo iluminismo, sendo considerado um dos precursores do movimento romântico. Para Rousseau os problemas sociais que causavam a infelicidade do homem teriam sua origem no momento que este decidiu se separar, isolar-se de sua mãe fecunda: a mãe natureza. Goethe inspirado pelas concepções roussenianas escreve:

O sentimento cabal, fervoroso do meu coração pela Natureza completa de vida que se inundava de infindáveis deleites, que transformava o mundo que me cerca num paraíso, está-se convertendo para mim num - verdugo insuportável, num espectro atormentador que me persegue por todos os caminhos. [...] Montanhas colossais faziam cerco em torno de mim, abismos abriam-se à minha frente e torrentes precipitavam-se impetuosamente, os rios corriam em fúria a meus pés, florestas e montanhas ressoavam formidáveis fragores; e eu via todas as forças misteriosas agindo e operando umas sobre as outras, nas profundezas da terra; e à superfície, sob o firmamento, fervilhavam todas as espécies de múltiplos seres. Tudo, tudo repleto de milhares de formas; e os homens, depois, protegendo-se juntos em arremedos de casas e, em pensamento, reinando sobre o vasto Universo! Pobre louco, que consideras tudo tão insignificante, sendo tu tão ínfimo (GÖETHE, 1982, p. 51).

\section{A GEOGRAFIA DE ALEXANDER VON HUMBOLDT}

É neste contexto romântico e ao mesmo tempo positivista, que Humboldt escreve seus trabalhos e ao longo de sua obra, podem ser encontrados fragmentos que atestem esta dupla filiação. Como exemplo dos ideais românticos, cita-se a concepção de natureza utilizada por Humboldt e que dá suporte a toda sua obra.
No romantismo, a natureza traria ao homem a libertação de que necessita. Este ideal é claramente visualizado em Rousseau ao escrever que a libertação do homem viria por meio de um re-encontro com a mãe natureza. A este respeito, Gomes e Vechi (1992) escrevem que, para Rousseau, o modelo da reforma individual e social para a recuperação do "eu" individual (esmagado pela coletividade da sociedade moderna) estava no seio da Natureza. Assim, Rousseau defendia que para reerguer-se moralmente, o homem deveria procurar o contato emotivo com tudo o que era natural. Influenciado por esta concepção Humboldt escreve:

O simples contato do homem com a natureza, a influência do grande ambiente, e como dizem outras línguas valendo-se de uma expressão mais bela aire libre, produzem um efeito calmante, mitigando a dor e aquietando as mais profundas e agitadas pasiones da alma (HUMBOLDT, 2005a, p. 20).

A visão romântica sobre a Natureza era uma visão holística por excelência, sendo a natureza um organismo capaz de desenvolver criativamente suas potencialidades inerentes, ao longo do tempo. Essa natureza estaria além do mundo e aquém de Deus, seria como um todo-poderoso. Para Nunes (1985), a Natureza nos românticos era entendida como realidade cósmica, benéfica e luminosa. A natureza consolava o homem das penas e fadigas da existência e permitia à alma "voar através dos campos como se voasse para casa".

Desta forma, no romantismo a natureza era vista como uma grande rede viva de relações, um grande "eu". Para os românticos, o homem tinha de reencontrar o contato com a "alma do mundo", assim como faziam os antigos povos ditos "primitivos". Influenciado por estas concepções, Humboldt para definir natureza, cita Schelling, que diz "não ser a natureza uma massa inerte, e, sim, a força criadora do universo, força que age incessantemente, primitiva, eterna e que renasce por seu turno" (HUMBOLDT, 1950a, p. 27)".

Nas palavras de Capel (1988), o grandioso projeto científico, que Humboldt tratou de "mimar" durante toda sua vida, objetivou demonstrar empiricamente essa concepção idealista da harmonia universal da natureza concebida como um todo único composto de partes intimamente relacionadas, num todo harmonioso movido por forças internas.

7 Descartes foi um dos maiores responsáveis pela nítida divisão e aceitação cultural entre o psicológico e a realidade física, divisão essa que vem imperando durante os últimos três séculos, com consequências funestas para a humanidade. Assim, o pensar dos românticos era algo eminentemente oposto ao pensamento de Descartes. Enquanto para este só existia alma no ser humano, para os românticos, toda a natureza era plena de espíritos. 
Racionalmente considerada a natureza, quer dizer, submetida a elaboração da inteligência, não é mais que a unidade dentro da diversidade dos fenômenos, a harmonia entre todas as coisas criadas desemejantes em sua forma, em sua constituição própria e nas forças que animam o todo penetrado por um sopro de vida. [...] O resultado mais importante do estudo racional da natureza é a compreensão da unidade e da harmonia em meio ao imenso agregado de coisas e forças; compreensão que nos leva a abraçar com igual ardor os descobrimentos de épocas anteriores (HUMBOLDT, 2005a, p.19).

Ainda de acordo com Moraes (2002), o pai da Geografia Moderna interpreta seus próprios trabalhos como se fosse uma "Filosofia da Natureza" com base empírica atribuindo-Ihe assim também caráter de ciência.

[...] a filosofia da natureza se desprende das formas vagas e poeticas proprias de sua origem, adota um carater mais severo, inclui o valor das observações e já não se entrega à advinhação como antes, e nem à relação e ao raciocinio (HUMBOLDT, 2005a, p.18-19).

Assim, a Geografia seria uma reflexão sobre os conhecimentos dados pela observação ordenada do mundo: conhecimento sensível ao mesmo tempo que é racional e empirico. Neste aspecto, Vitte (2007) salienta que o projeto de Humboldt foi o resultado da união do empirismo de Bacon com a filosofia da natureza de Göethe e Schelling, na tentativa de descobrir a harmonia e a beleza do organismo cujas partes estariam equilibradas e mutuamente interdependentes.

[...] o grande carater de uma paisagem, como de toda uma cena importante da natureza, depende da simultaniedade das ideias, dos sentimentos existentes no observador. Poderiamos dizer que o poder da natureza se revela pela conexão das percepções, na unidade das emoções e nos efeitos produzidos a certo modo de uma só vez [...] (HUMBOLDT, 2005a, p. 22).

Outro aspecto que merece consideração neste texto se refere à concepção que se tem dos trabalhos desenvolvidos por Humboldt. Segundo Capel (1988) seus escritos não podem ser classificados simplesmente como trabalhos de cunho eminentemente descritivos. Pelo contrário, Alexander von Humboldt indagava-se constantemente sobre a relação entre os fenômenos sempre buscando uma possível explicação cientifica. Assim:

O estudo filosófico da natureza não poderia ficar encerrado nos limites de simples descrição; é alguma coisa mais que a estéril aproximação de fenômenos isolados. Seja, pois, lícito à curiosa actividade do homem, elevar-se desde o presente às trevas do passado, pressendir o que ainda não pode ser ostensível, e comprazer-se nesses antigos mitos geológicos que sempre reaparecem sob novas formas (HUMBOLDT, 1950b, p. 182)

Ressalta-se ainda que alguns aspectos relacionados aos métodos utilizados por este autor destacaramse dentro da perspectiva geográfica. Capel (1988) salienta que o método utilizado por Humboldt mesclava a descrição, a comparação de áreas e ao mesmo tempo incorporava uma perspectiva histórica. Tal afirmação justifica-se a seguir:

[...] o caráter especial da ciência é sempre a contemplação das coisas criadas, encadeadas entre elas e formando um todo, animado por forças interiores. A descrição física do globo mostra, diz ainda, o quadro do que coexiste no espaço, da ação simultânea das forças da Natureza e dos fenômenos que elas produzem; traçando o quadro físico do globo, vê-se, por assim dizer, o presente e o passado se penetrarem reciprocamente, pois, por exemplo, a forma das rochas é a sua própria história (HUMBOLDT, 1950a, p. 28).

Neste contexto ressalta-se ainda que muitas das ideias de Humboldt seriam posteriormente classificadas como ideias geográficas, não somente, mas particularmente no campo da Geografia física. Assim, a geografia científica deve contribuições que abrangem vários de seus sub-ramos, como: geomorfologia, biogeografia, cartografia, geografia política, entre outros, como será mostrado a seguir.

Biogeografia. Humbold estudou as plantas correlacionando características biológicas com fatores ambientais que segundo ele teriam uma relação direta. A seguir um trecho que contempla esta afirmação:

Convém também notar que a distribuição das formas vegetais não depende unicamente da latitude geográfica nem mesmo da latitude isotérmica. [...] A distribuição dos seres orgânicos na superfície da terra não procede só das relações complexas que nascem da temperatura e dos climas, provem também de causas geológicas, produzidas pelo estado primitivo da Terra e por catástrofes quase totalmente desconhecidas e cujos efeitos foram sentidos simultaneamente em todos os pontos do nosso planeta (HUMBOLDT, 1950b, p. 45-46).

Em suas observações, estabeleceu correlações entre o tipo de clima e o tipo de solo na definição da presença ou não de determinadas espécies de plantas, relacionando fatores climáticos e formações vegetais. 
Nestes estudos, Humboldt teria realizado também uma espécie de zoneamento. Assim:

A região florestal tem tríplice influencia: atua, a um tempo, pela frescura da sombra que espalha, pela evaporação das águas que absorve, e pela irradiação que refresca a temperatura (HUMBOLDT, 1950a, p. 114).

A figura 1 intitulada por Humboldt de "Geografia das Plantas Equinociais", em sua parte central, tem representado o que supostamente seria uma montanha e nela aparecem os nomes das plantas como forma de localizar a altitude em que foram encontradas. Do lado esquerdo e direito deste desenho aparecem tabelas que acrescentariam outras informações obtidas como: altura, latitude, pressão e temperatura dos locais estudados. Para identificar e localizar as plantas estudadas, Humbold traçava um perfil vertical, indicando distancias horizontais e verticais, escrevendo o próprio nome da planta no local onde ela fora encontrada.

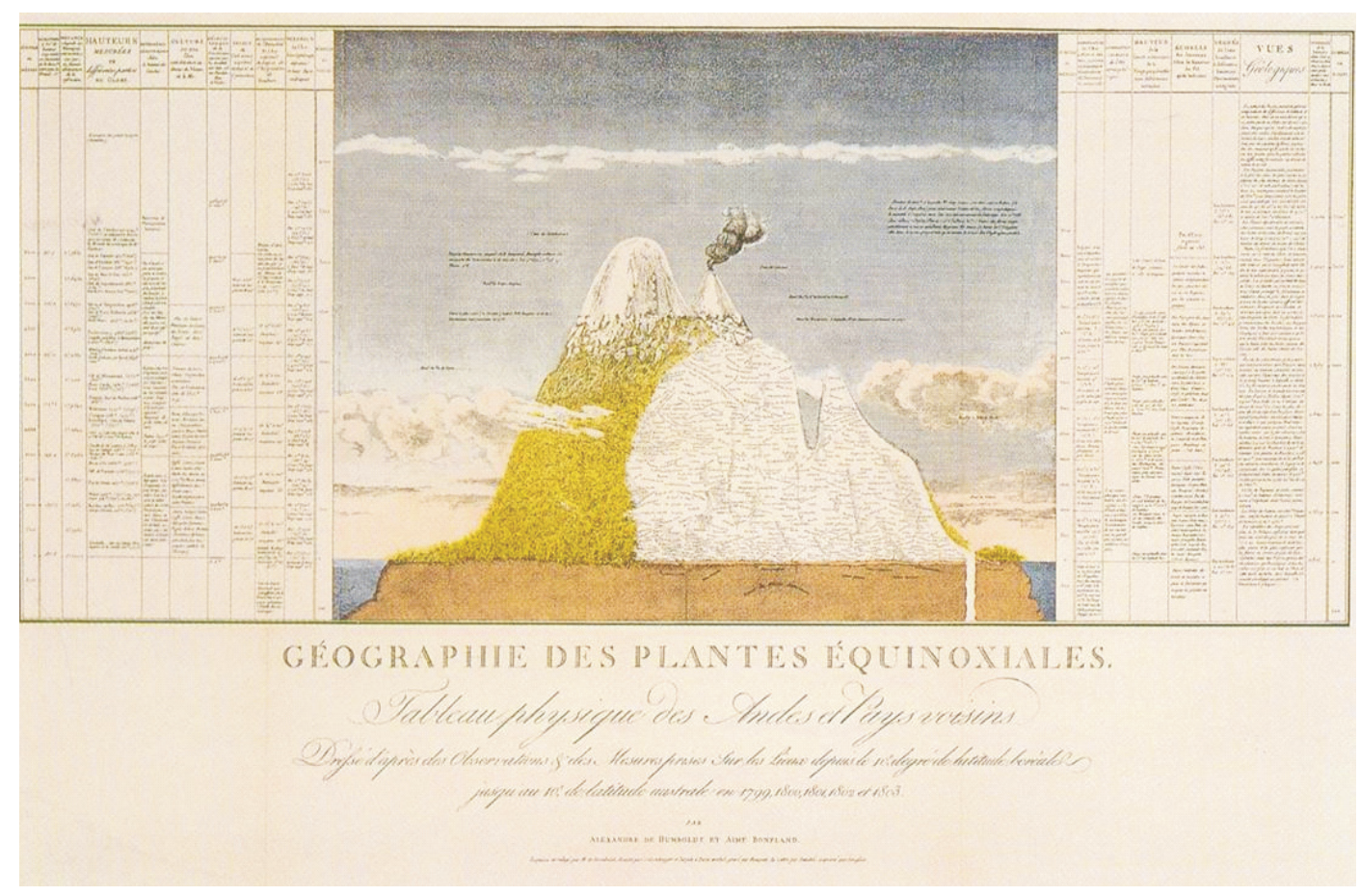

FIGURA 1 - GEOGRAFIA DAS PLANTAS EQUINOCIAIS

FONTE: Feisst (1978), organizado por Springer (2009).

Já na figura 2, a relação que se faz não é com a altitude e sim com a latitude. Conforme pode ser observado, estabelece-se uma relação entre latitude, zonas climáticas e vegetação. Na figura Humboldt identifica três zonas distintas: Heisse Zone, gemäßigte Zone e kalte Zone ${ }^{8}$ cada qual localizada em uma faixa do globo e com uma vegetação característica (perceba que a figura lembra o formato do globo terrestre). 


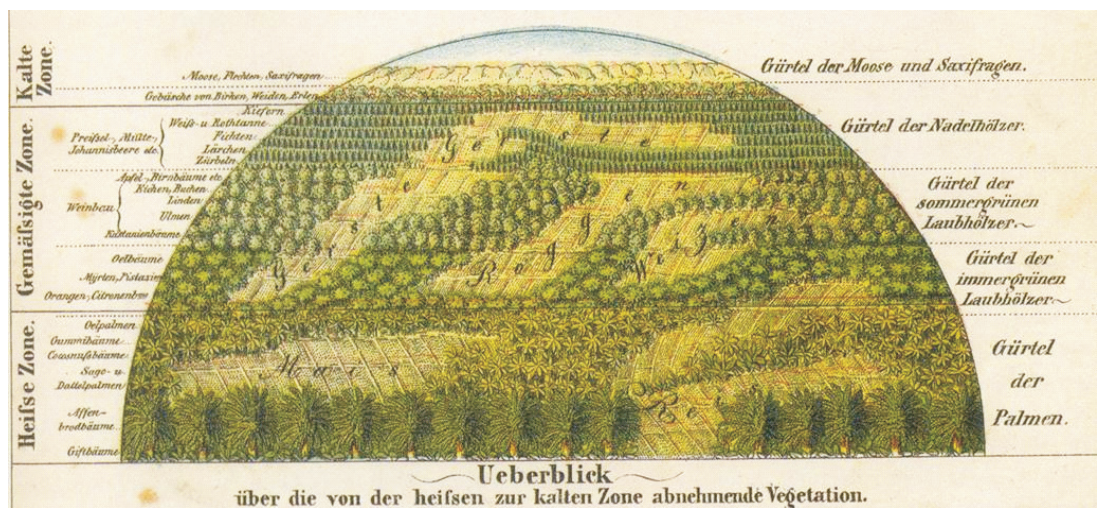

FIGURA 2 - AS ZONAS DE CALOR DA TERRA

FONTE: Feisst (1978), organizado por Springer (2009)

Geomorfologia. Nos estudos geomorfológicos, Alexander Von Humbold contribuiu principalmente no se refere à descrição das formas da Terra estabelecendo comparações: diferenças e semelhanças entre os diversos locais que conheceu e investigou cientificamente. Como exemplo cita-se um trecho do capitulo I, acerca das planícies existentes ao longo do planeta:

Em todas as zonas a natureza apresenta os fenômenos destas planícies sem fim, mas em cada região têm elas caráter particular e fisionomia própria, derivados da constituição do solo, diferenças de clima e elevação sobre o nível do mar. Ao norte da Europa podem ser considerados verdadeiros estepes [...] nos quais uma só espécie de planta afoga qualquer outra vegetação.
[...] (p. 06)As planícies situadas no interior da África [...] Fazem parte de um mar de areia que, para o lado do oriente, separa uma das outras, varias regiões férteis, ou as converte em ilhas, envolvendo-as por todos os lados (HUMBOLDT, 1950a, p. 7).

Os aspectos geormofológicos também eram apresentados cartograficamente, conforme figuras 3 e 4. A figura 3 representa a descrição geomorfológica de uma região situada no México. Apesar de não ter legenda, fica claro que os desenhos no interior do mapa, indicam possíveis feições geomorfológicas encontradas naquela região. Pode-se considerar inclusive que para a época é uma representação bastante detalhada do relevo daquela região.

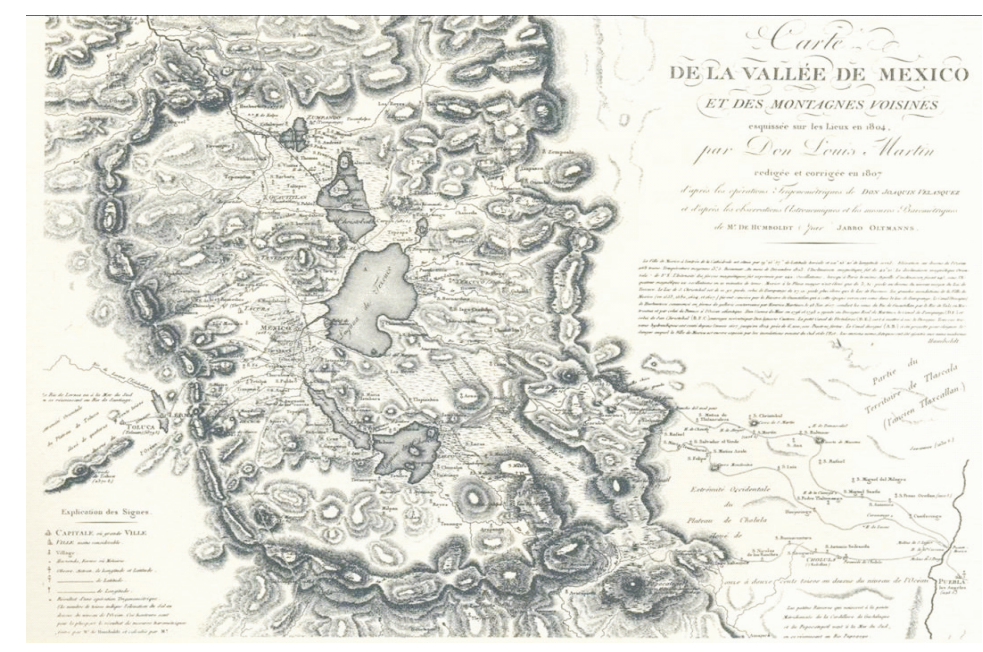

FIGURA 3 - CARTA DO VALE DO MÉXICO

FONTE: Feisst (1978), organizado por Springer (2009) 
Já na figura 4 , a representação do perfil topográfico evidencia a preocupação com as relações entre superfície horizontal e dados altimétricos. Em capítulo que discorre acerca do Deserto do Saara, escreve:
Denominações expressivas, e, entre outras, as que se aplicam à forma exterior e ao relevo da terra, nascidas em uma época que havia apenas conhecimento muito incerto do solo e das suas relações hipsométricas, foram muitas vezes a causa de obstinados erros em geografia (HUMBOLDT, 1950a, p. 99).

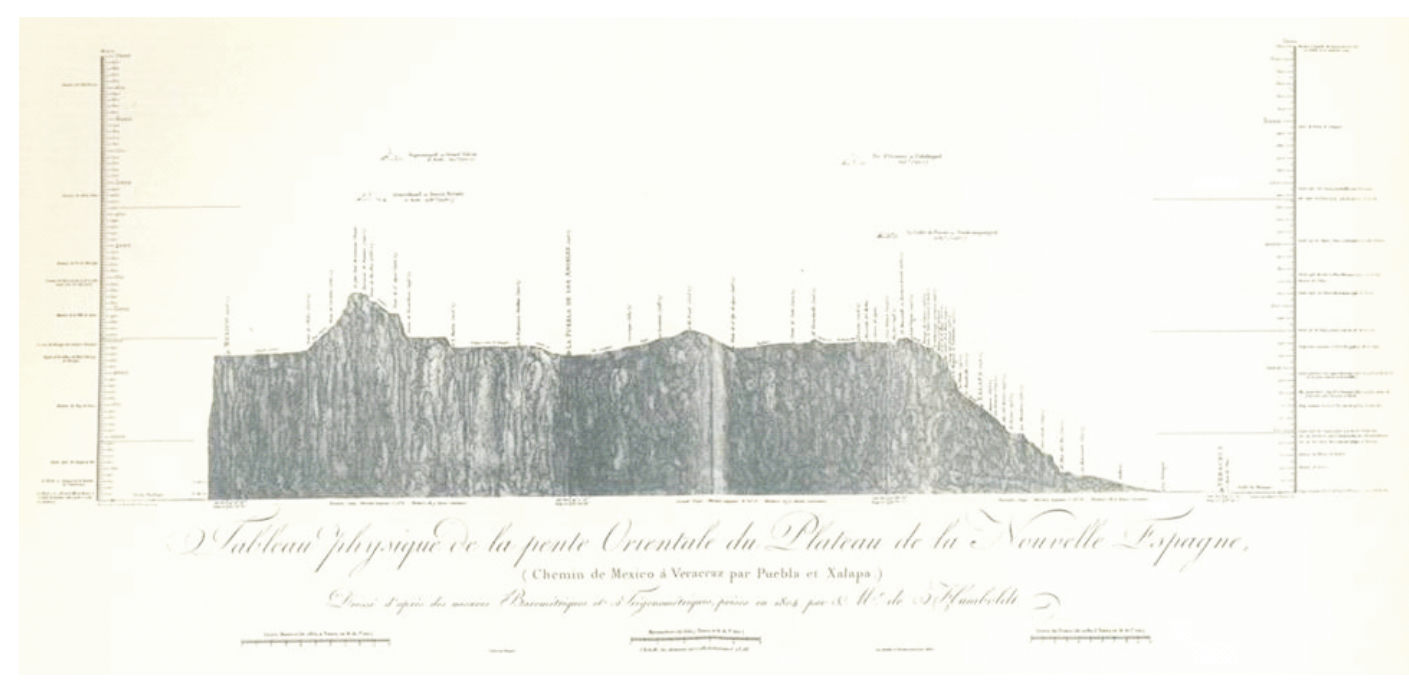

FIGURA 4 - PERFIL TOPOGRÁFICO

FONTE: Feisst (1978), organizado por Springer (2009).

Climatologia. Para os estudos em climatologia, Humboldt identificou e mapeou correntes marítimas, mediu e monitorou pluviosidades, temperaturas do ar e da água, mediu, monitorou e fez relações entre temperatura, umidade do ar e pressão atmosférica elaborou e desenvolveu isogramas, espacializou dados coletados, relacionou latitude e tipos climáticos e temperatura. $\mathrm{A}$ seguir apresenta-se trecho da obra em que é feita a relação entre as massas de ar, umidade, temperatura e vegetação:

[...] a estrutura interior do solo africano e a situação deste país, com relação as massas continentais que 0 rodeiam, produzem a seca extrema que, em espaços imensos, se opõe ao desenvolvimento da vida orgânica (p. 13). Além do efeito dos ventos quentes, é preciso ter presente na África, ou pelo menos, nas partes que deste continente conhecemos, a falta de grandes rios, de montanhas elevadas e de bosques que produzem um vapor aquoso e mantêm a frescura (HUMBOLDT, 1950a, p. 14).
Outros exemplos de estudos em climatologia podem ser identificados nas figuras 5 e 6 . A figura 6 apresenta duas correntes marítimas: na costa leste da América do sul e América Central apareceria a corrente equatorial e na costa oeste a corrente do Peru. Esta última posteriormente receberia seu nome como uma forma de homenagear seu descobridor. Além da representação propriamente dita, aparecem escritos nos mapas detalhes como a temperatura da água (a corrente do Peru seria em média $4^{\circ}$ a $5^{\circ}$ mais fria que as águas em seu entorno) e a diferença na temperatura da água e do ar conforme a época do ano. Identificase também uma tabela no centro da figura, em que se estabelece novamente relação entre os meses do ano, temperatura do ar e da água na cidade de Lima no Peru e as coordenadas geográficas. 


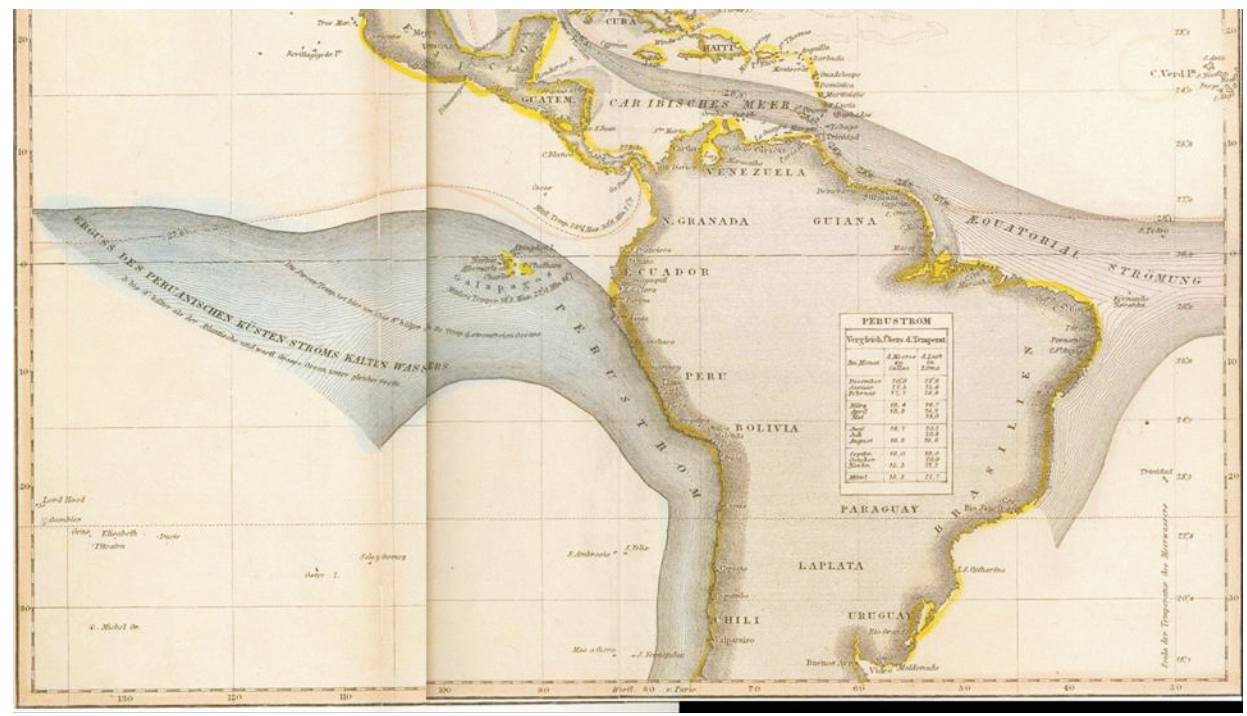

FIGURA 5 - CORRENTES MARÍTIMAS

FONTE: Feisst (1978), organizado por Springer (2009).

A figura 6 constitui-se em uma representação cartográfica denominada de schnee-karte ${ }^{9}$. Na figura aparecem dois globos: no lado esquerdo tem-se no centro o polo norte e no lado direito o polo sul. Nesta representação de projeção cônica, os países aparecem relacionados com sua latitude em quatro faixas representadas por distintas cores. A cor branca, localizada na parte central dos dois globos representaria os locais que, segundo Humboldt, teriam neve permanentemente.
Seguindo em direção à extremidade ${ }^{10}$, o circulo imediatamente posterior ao branco indicaria áreas onde haveria presença de neves somente em determinadas épocas do ano (seriam as "neves temporárias"). Já o circulo maior representaria aqueles locais que estariam isentos da ocorrência das "neves". Ao redor do globo aparece ainda uma aureola de cor amarela, nela tem-se identificado as coordenadas geográficas.

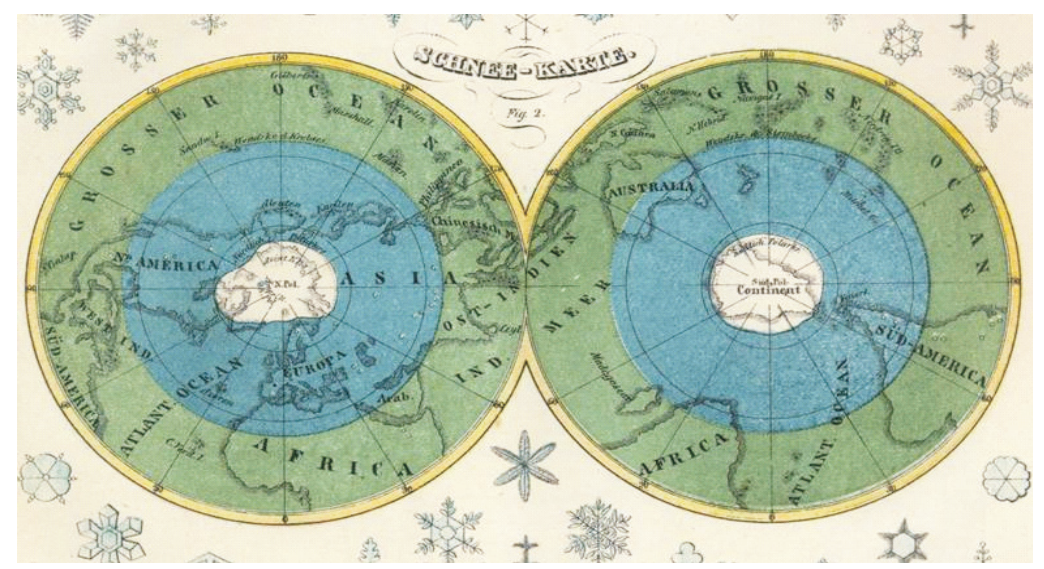

FIGURA 6 - CARTA DE NEVES

FONTE: Feisst (1978), organizado por Springer (2009).

9 Carta de Neves.

$10 \mathrm{Na}$ figura original, a sequência de cores do centro às extremidades é: branco, azul e verde. 
Cartografia. As representações cartográficas elaboradas por Humboldt compreendem um passo importante para o avanço da ciência. Para os conhecimentos e a tecnologia da época, estas representações podem ser consideradas, no aspecto estético, como verdadeiras obras de arte e inquestionáveis instrumentos de representação da superfície terrestre no campo cientifico ${ }^{11}$. A determinação da altitude e da localização astronômica, bem como as medições trigonométricas e os meios para a comparação espacial de certos fenômenos naturais e humanos, formavam a base do mapeamento da paisagem realizado por Humboldt. Em alguns trabalhos, procurava estabelecer relações entre os fenômenos representados, como se pode verificar na citação a seguir:

O mapa das cadeias de montanhas e dos vulcões da Ásia Central, que eu tracei em 1839 e foi publicado em 1843, faz ressaltar completamente as relações hipsométricas que existem entre as montanhas e a planura de Gobi (HUMBOLDT, 1950a, p. 70).

Algumas representações podem ser apreciadas nas figuras 7 e 8 . A figura 7 representa a "Carta da América Meridional". Este mapa abrange a porção norte da atual América do Sul. Nesta representação espacializou-se com incrível detalhamento (mesmo sem ter entrado nesta parte do Brasil) aspectos físicos e políticos de grande parte do norte/nordeste de nosso território. No mapa, as linhas ${ }^{12}$ indicam ora a hidrografia da região, ora delimitam as áreas coloniais. Estas áreas indicavam com seus nomes suas metrópoles: Guyane Française, Guyane Espagnole, Guyane Portugalse, Guyane Hollandaise.

A figura 8 representa a América Central. Neste mapa aparecem identificados detalhes como os Golfos do Panamá, de Honduras, de Fonseca, a Península e o Golfo de Nicoya, os Lagos Nicarágua e Manágua (denominado de Leon Pubindiri) as ilhas oceânicas da costa leste, entre elas a parte do Haiti, a Jamaica, as ilhas Cayman (grande e pequena) e boa parte das ilhas que compõem as Grandes Antilhas ${ }^{13}$. Observando-se estas representações (e claro não somente estas) e comparando-as com os mapas atuais, ressalvo alguns detalhes é impressionante o grau de similaridade.
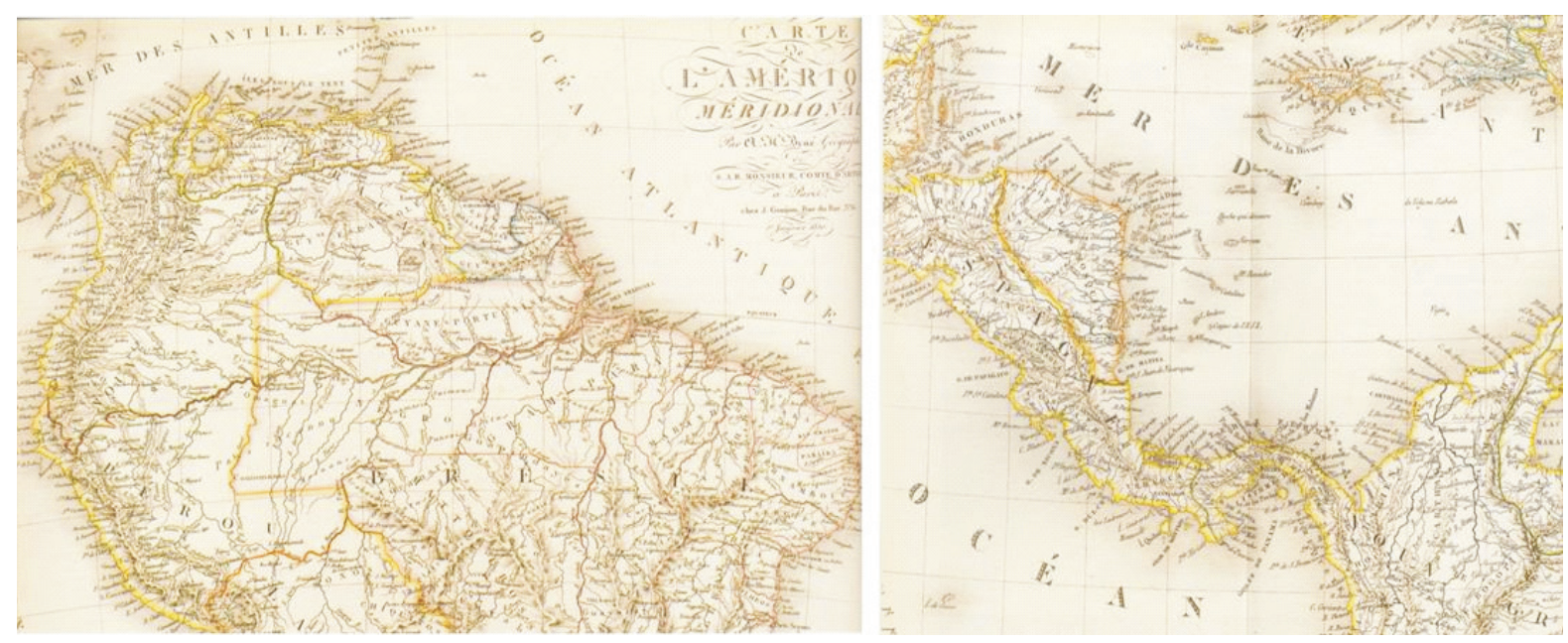

FIGURAS 7 E 8 - AMÉRICAS CENTRAL E MERIDIONAL

FONTE: Feisst (1978), organizado por Springer (2009).

11 Em várias representações aparecem os elementos cartográficos: coordenadas geográficas, título, legenda, identificação do organizador e escala.

$12 \mathrm{Na}$ figura original, a rede hidrográfica aparece em azul e a delimitação dos territórios é feita em amarelo.

$13 \mathrm{Na}$ figura original destes mapas aparecem linhas em amarelo e laranja e azul. Acredita-se que, para melhor separar e identificar a quais metrópoles os territórios eram pertencentes. 
A física do Globo. Humboldt procurou compreender alguns fenômenos de ocorrência dispersa no globo, os quais denominou de física do globo. Dentre estes fenômenos citam-se o magnetismo da Terra, os gases da atmosfera, estrutura geológica, vulcanismo, terremotos, entre tantos outros. Referindo-se ao caminho percorrido para se chegar à antiga cidade Inca de Micuipampa, escreve:

Este trajeto deu-se lugar a uma observação magnética de interesse geral para a ciência. Determinei o ponto em que a inclinação da agulha magnética passa do norte ao sul, ou, antes, o lugar em que o viajante corta o equador magnético (HUMBOLDT, 1950b, p. 224).

Outro exemplo de estudos sobre a física do globo refere-se aos fenômenos vulcânicos. Para o autor:

\begin{abstract}
Segundo este modo de ver as coisas, que expus já na obra intitulada: "Ensaio geognóstico sobre a natureza das rochas em ambos os hemisférios", a temperatura dos vulcões seria a temperatura mesma do corpo interior da terra, e as causas, que produzem hoje horríveis estragos, teriam feito brotar noutro tempo da crosta terrestre, recentemente oxidada, e sulcada ainda por profundas fendas, a vegetação vigorosa que se desenvolvia sob todas as zonas (HUMBOLDT, 1950b, p. 181 e 182).
\end{abstract}

Já, na figura 9, tem-se a representação de parte da crosta terrestre: a estrutura rochosa e os fenômenos vulcânicos. Podem-se evidenciar nomes conhecidos como gnaisse, basalto, lava, entre outros. Um aspecto interessante é a representação do vulcão com a lava subindo em direção à superfície.

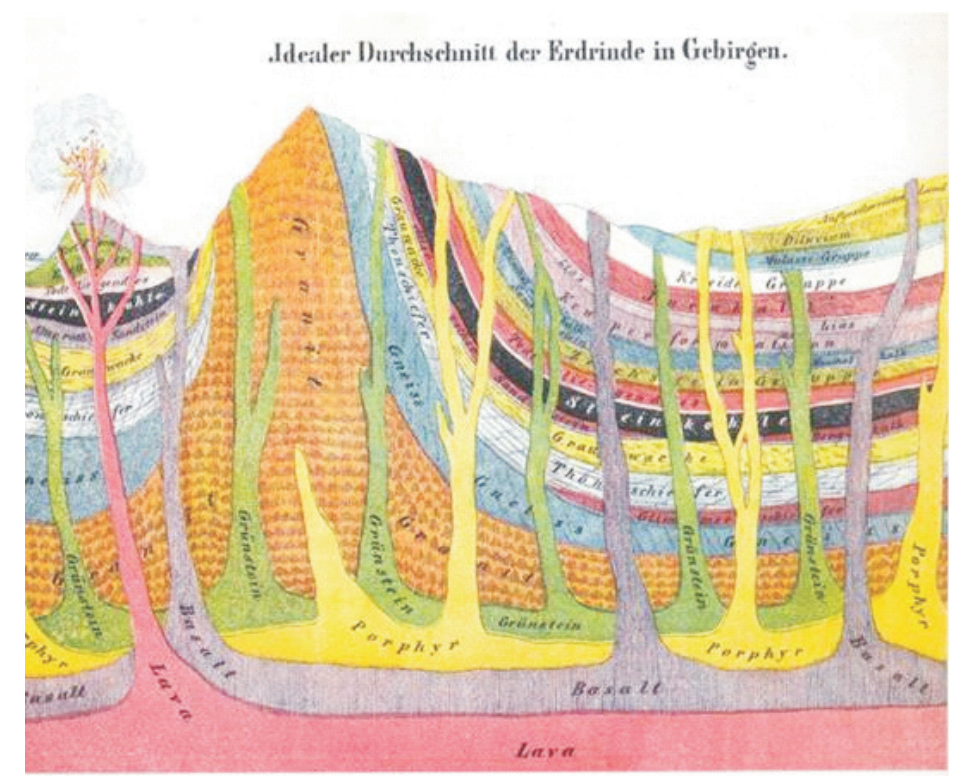

FIGURA 9 - ESTRUTURA GEOLÓGICA

FONTE: Feisst (1978), organizado por Springer (2009).

Hidrografia. A rede hidrográfica era cuidadosamente descrita nos textos e por vezes localizada e representada em cartas. Informações e dados como: extensão, espessura, direção do rio, profundidade, temperatura da água, fauna e flora existentes eram descritos e analisados. A citação a seguir exemplifica essa preocupação:

Fica-se indeciso, ao considerar a massa de água que o Orenoco lança no Oceano Atlântico, sobre qual dos três, o Orenoco, o Amazonas ou o Rio da Prata é o maior da América Meridional [...]. O Rio da Prata é o que apresenta maior embocadura, pois não tem menos de trinta e oito léguas de largura no sitio em que deságua no mar [...]. Já em Buenos Aires, a sua pouca profundidade é obstáculo à navegação. O Amazonas, pelo contrário é o mais largo de todos os rios; percorre uma extensão de mil e oitocentas léguas, desde o seu nascimento no lago Lauricocha até a embocadura [...] Mais estreito, o Orenoco do que o Rio da Prata e o Amazonas, não excede em comprimento, segundo minhas observações astronômicas, quatrocentos e sessenta e cindo léguas [...] (HUMBOLDT, 1950b, p. 215). 
No Brasil, em estudos realizados na Bacia do Rio Orenoco, Humboldt analisou o fenômeno que denominou de "águas negras":

Naveguei trezentas e oitentas léguas pelo interior do continente, desde as fronteiras do Brasil até as costas de Caracas, passando do Rio Negro ao Orenoco através do Casiquiári. Nesta parte superior do rigueiro, ente $3^{\circ}$ e $4^{\circ}$ graus de latitude norte a natureza renovou muitas vezes o misterioso fenômeno das chamadas águas negras. [...] Provavelmente devem estes a sua singular cor a uma dissolução de hidrogênio carbonado, à riqueza da vegetação tropical e à multiplicidade de plantas que lhe cobrem o leito (HUMBOLDT, 1950b, p. 218-219).
A transformação dos dados e das informações coletadas no campo em documentos cartográficos pode ser exemplificada nas figuras 10 e 11. Na figura 10 estão representados os rios Grande e Madalena. Conforme pôde ser evidenciado no texto ${ }^{14}$, neste rio Humboldt realizou estudo detalhado onde coletou amostras da água (temperatura), identificou posições geográficas, velocidade e direção da correnteza, mediu extensão total, a largura do leito, mapeou suas variações e observou os povos ribeirinhos. Já a Figura 11 apresenta vários tipos de bifurcações diferentes; entre os rios representados aparecem Rio Yapure, Amazonas e Rio Negro.

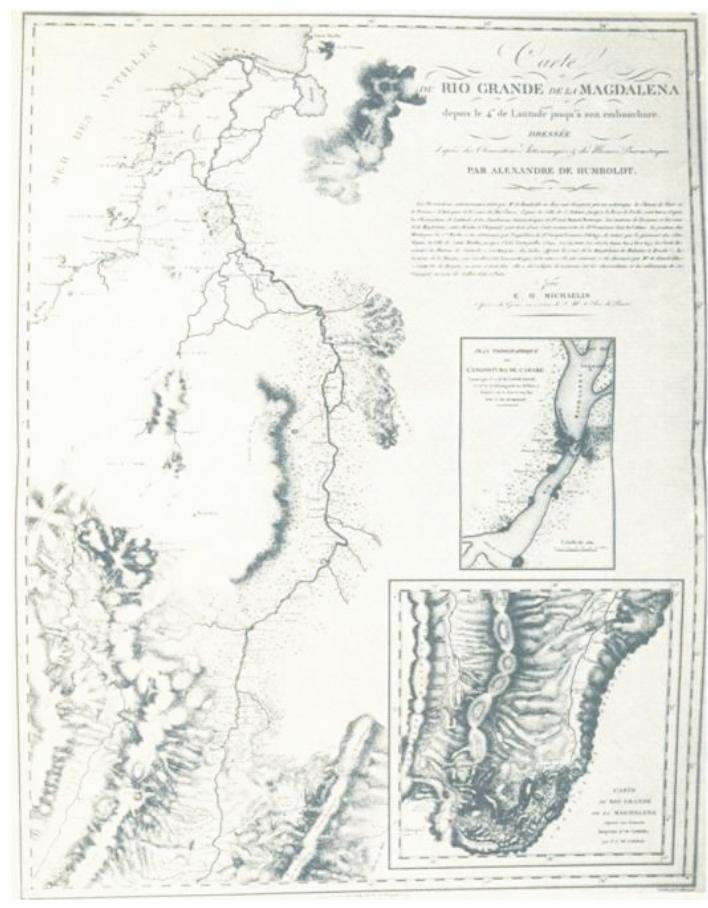

FIGURA 10 E 11 - REDE HIDROGRÁFICA

FONTE: Feisst (1978), orgnaizado por Springer (2009).
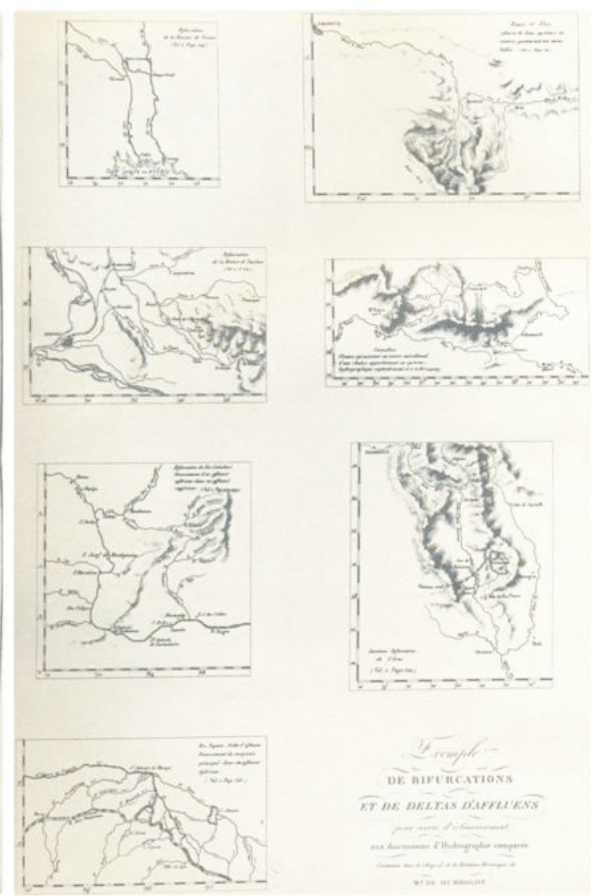

Geografia dos Animais. A referência aos animais é constante, sendo estes estudados e analisados sob variados aspectos. Sua importância para o homem era um dos interesses do autor:

Nas poesias orientais, chama-se ao camelo o navio terrestre ou a nave do deserto. Os camelos, porem, não servem unicamente para transporte dos fardos; não são apenas um meio de locomoção próprio para unir entre si regiões afastadas, mas também segundo o nota Carlos Ritter, na sua excelente dissertação sobre acerca dos limites geográficos em que se acham distribuídos estes animais "a condição essencial da vida nômade nas regiões abrasadadoras, nada ou muito pouco visitadas pelas chuvas, nesse grau de civilização em que reina a vida patriarcal" (HUMBOLDT, 1950a, p. 63). 
Realizou também observações, descrições, esboçou desenhos e quando possível estabeleceu comparações entre os animais de mesma raça, ou raças diferentes localizados em locais diferentes do globo terrestre. Assim, Humboldt escreve:

Os cães do Peru representavam o seu papel nos eclipses da lua, pois batiam-lhes até acabar o eclipse. O cão mexicano Techichi tinha o caráter distintivo de ser completamente mudo. É, enquanto ao mais, uma variedade do cão comum, chamado Chichi em Anahuac.
Techichi significa literalmente cão de pedra, da voz asteca tell, pedra. O cão mudo servia de alimento como era de uso entre os antigos chineses, e até os próprios espanhóis fizeram deles tão grande consumo, forçados pela necessidade, que desapareceu quase completamente (HUMBOLDT, 1950a, p. 94).

Outro exemplo de estudo desenvolvido pode ser evidenciado na figura 12. Nesta imagem, tem-se a relação entre as espécies e os locais onde foram encontradas.

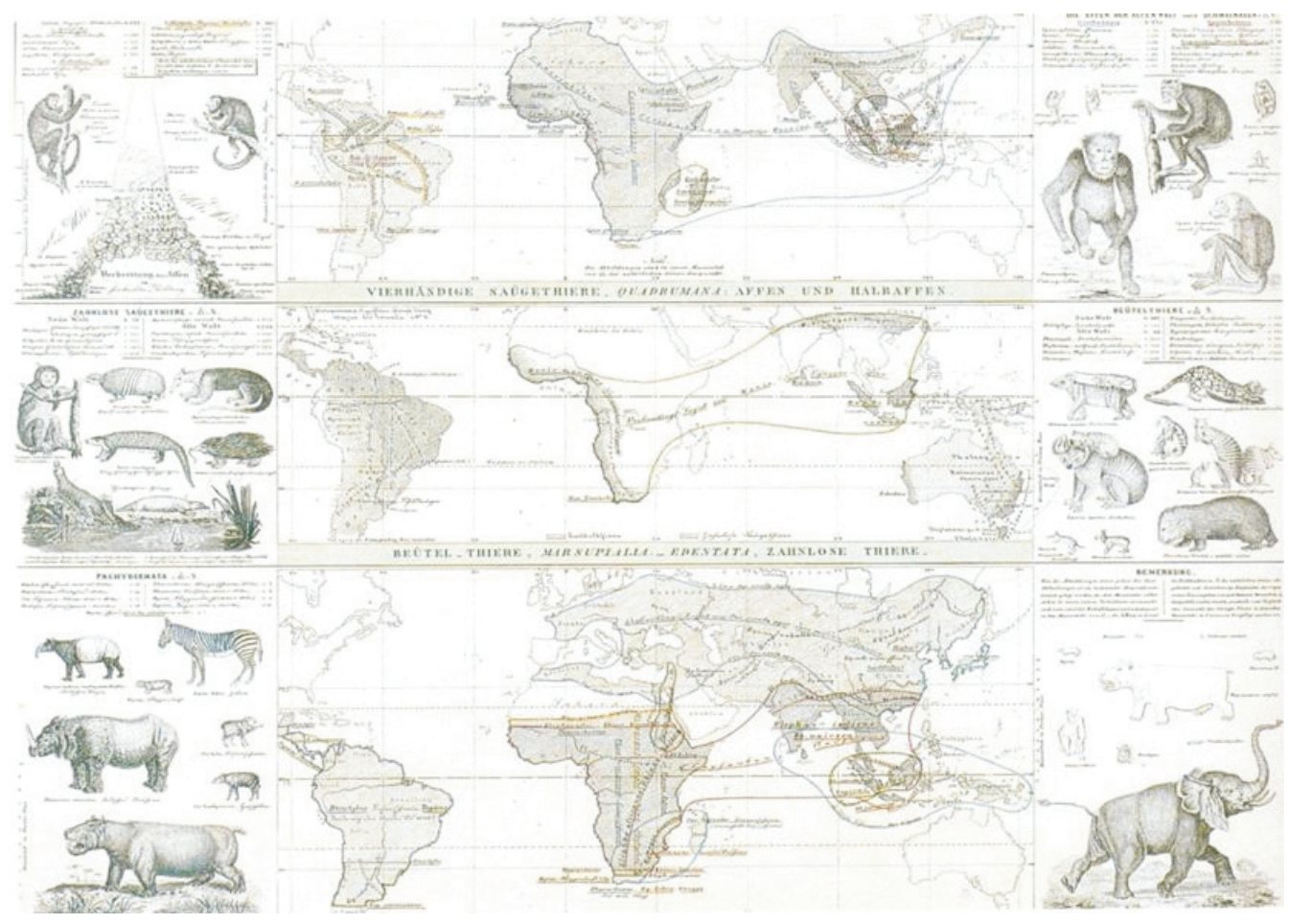

FIGURA 12 - A GEOGRAFIA DOS ANIMAIS

FONTE: Feisst (1978), organizado por Springer (2009).

É possível identificar ainda, a relação que Humboldt estabelece entre as condições ambientais (temperatura, pressão, umidade) e sua influência no comportamento e nas características dos animais. Como exemplo cita-se:

Tschud conseguiu a singular observação de que, nas Cordilheiras, e em alturas que passam de 3.898 metros, os cães de organização delicadas, como também os gatos domésticos da Europa, estão sujeitos a uma enfermidade particular e mortal. [...]; cães e gatos, ao cabo de alguns dias morriam em horríveis convulsões.
Os gatos, vitimas desta doença, sobem às paredes e caem desfalecidos e sem movimento, o que parece causado pela insuficiência da pressão atmosférica (HUMBOLDT, 1950a, p. 95).

Geografia do Homem. Diferentemente da concepção que muitos geógrafos têm a respeito da obra de Humboldt; em seus escritos podem ser encontrados também estudos sobre economia, transporte, costumes e características gerais das populações por ele analisadas. Entre os quais se cita as populações indígenas: 
SPRINGER, K. Considerações acerca da geografia de Alexander Von Humboldt...

A civilização do México, ou seja do país de Anahuac, habitado pelos Astecas, e da teocracia peruana, governada pelos filhos do Sol, tem atraído completamente, por muito tempo, uma terceira civilização que começa entre os povos montanheses de Nova Granada. A forma de governo, estabelecida entre os Muíscas de Nova Granada lembra a constituição do Japão e as relações do imperador secular [...]. Tinham os Muíscas um cômputo regular do tempo e supriam com intercalações a insuficiência ao ano lunar [...]. (p. 239). Usavam como moeda pequenos discos de ouro fundido [...] (HUMBOLDT, 1950b, p. 239 e 240).

Em sua obra aparecem também trechos em que demonstra clara admiração pelos povos indígenas:

É precisamente nestas regiões que subsistem ainda admiráveis restos da grande via reconstruída pelos Incas, dessa obra gigantesca que estabelecia comunicação entre todas as províncias do império, em uma extensão de mais de 400 leguas. [...] Nenhum das vias romanas que vi em Itália, no Meio-dia da França, em França, era mais imponente do que estas obras dos antigos peruanos (HUMBOLDT, 1950b, p. 210, 211).

Alguns textos evidenciam ainda a preocupação e, às vezes, certa revolta, quanto à destruição de antigas populações, em face à colonização:

Pouco se conservou também na cidade, hoje adornada por igrejas, da fortaleza e palácio de Ataualpo ${ }^{15}$. A destruição acelerou-se pelo ardor imprudente com que os conquistadores avarentos removeram as paredes e alicerces de todas as habitações, a fim de desenterrarem tesouros que supunham escondidos profundamente (HUMBOLDT, 1950b, p. 225).

\section{CONSIDERAÇÕES FINAIS}

Correntemente, os clássicos são raramente lidos e o discurso sobre o passado é realizado de forma indireta com leituras e argumentos já escritos sobre as antigas obras e não sobre a leitura direta das mesmas. Isso evidencia a necessidade de se rever determinadas posturas, que ao contrário do que se pensa, não indicam um profundo conhecimento dos clássicos. É preciso transpor o "juízo de valores" acumulado e compreender os trabalhos dentro de seu contexto filosófico, histórico e cientifico específico, sendo possível somente desta forma seu entendimento pleno.

Neste contexto, Alexander von Humboldt, diferentemente da imagem que boa parte dos próprios
Geografia Política e Econômica. Humboldt desenvolveu estudo sobre o Reino da Nova Espanha. Neste estudo, o autor faz menção à importância política da ilha: relaciona a extensão da ilha à fertilidade do solo potencializando a produção de produtos como açúcar, café, tabaco e cera e as questões de poder político e econômico que estas envolveriam. Humboldt pondera também sobre o poderio marítimo da ilha, as características da população composta por escravos e homens livres. Além disso, desenvolveu estudo sobre os bairros de Havana, em que estes bairros eram analisados segundo a composição de seus habitantes. De acordo com Pereira (1999) esta foi a primeira obra de cunho geográfico a empregar uma metodologia científica. Assim:

\begin{abstract}
Esta obra que publico se divide em seis sessões principais. O primeiro livro apresenta considerações sobre a extensão e o aspecto físico da Nova - Espanha. Sem entrar em nenhum pormenor da história natural descritiva, porque isto reservo para outras partes de minha obra, examino a influencia das desigualdades do solo e do clima, a agricultura, o comércio e a defesa das costas. O segundo livro trata da população geral e das varias castas em que se dividi. O terceiro apresenta a estatística particular de cada umas das intendências, sua população e sua área calculada segundo as cartas topográficas que eu fiz com minhas observações astronômicas. No quarto livro examino o estado da agricultura e mineração de metais, e no quinto os progressos das indústrias e comércio. O sexto livro contém uma pesquisa sobre as rendas do Estado e a defesa militar do país (HUMBOLDT, 1822, p. 3-4).
\end{abstract}

geógrafos tem a seu respeito, não foi somente um enciclopedista que se preocupava unicamente com a descrição dos locais aos quais estudava. A Humboldt devem-se algumas contribuições, muitas ainda aceitas dentro do conhecimento científico.

Como pesquisador, era dotado de enorme capacidade de observação aliado a uma infinita curiosidade, buscou o rigor e a exatidão científica. Diversas são as áreas do conhecimento que tem em Humboldt um dos seus precursores científicos. Para a Geografia Científica, contribuiu diretamente no desenvolvimento do que hoje se conhece como ciência geográfica. Como geógrafo abordou aspectos climáticos, fitogeográficos, 
geopolíticos, cartográficos, ele foi geográfico físico e humano, contribuindo para o desenvolvimento da moderna geografia.

Para Humboldt, a Geografia se ramificava em "Geografia Geral" e "Geografia Especial". E estudaria a natureza e o homem como partes integrantes de um todo. A "Geografia Geral" abarcaria o estudo geral da Terra em seus aspectos naturais e sociais, que seriam observados e analisados em uma sequência de sete áreas pelo globo terrestre. Já a "Geografia Especial" desenvolveria o conhecimento sobre os paises, cada um estudado e analisado em separado com suas particularidades naturais e sociais; era a denominada Länderkunde. Em sua Länderkunde escreveu obras acerca de vários países do "novo mundo" e, entre eles, parte do território Brasileiro, áreas estas visitadas e estudadas por ele durante a longa expedição que fez ao "Novo Continente".

Esta expedição realizada ao continente americano teve duração de cinco anos (1799-1804) $)^{16}$. Humboldt e Bompland passaram por territórios pertencentes hoje a vários paises americanos: Venezuela, Cuba, Caribe, México, Chile, Colômbia, Equador ${ }^{17}$, Peru e Estados Unidos. Na região Amazônica, navegaram em uma canoa indígena por meses, estudando parte da Bacia do rio Orenoco ${ }^{18}$. O percurso percorrido por Humboldt e Bompland nesta expedição às Américas, pode ser observado na figura 13, em que se encontra representado um mapa da época, o traçado mais espesso indica o caminho percorrido pelos dois pesquisadores.

Muitos cientistas atribuem a Alexander von Humboldt a criação da "imagem" do "Novo Mundo" na Europa. Como frutos desta expedição surgiram várias obras, dentre elas cita-se "Vom Orinoko zum Amazonas: Reize in die äquinoktial - gegenden des neuen kontinents" e " Ensayo Politico sobre el Reyno de La Nueva - España":

Espero que a obra em parcicular com o titulo de Ensaio Politico sobre o Reino da Nova Espanha, possa ser recebida com apreço, em uma época em que o novo continente, mais do que nunca, tem a atenção e o interesse dos europeus (HUMBOLDT, 1822, p. 2).
No entanto, segundo Gabaglia (1950)19 o Ansichten der Natür ${ }^{20}$ é a obra que traz maiores informações acerca dos paises da América do Sul. Foram registradas observações, descrições e considerações a respeito dos aspectos naturais e humanos referentes aos locais visitados. Ainda de acordo com Gabaglia (1950) a coleção total desta obra, compreende vinte e três volumes, sendo considerada o maior compêndio sobre uma viagem empreendida por um particular do qual se tem informação. Segundo Beck (1999), Humboldt gastou parte de sua riqueza financiando a viagem e posteriormente redação e publicação de seus resultados. Para exemplificar a magnitude da viagem, Beck (1999) escreve que os cientistas coletaram, identificaram e descreveram, ainda durante a viagem cerca de 5.800 amostras de plantas, das quais 3.600 eram ainda desconhecidas.

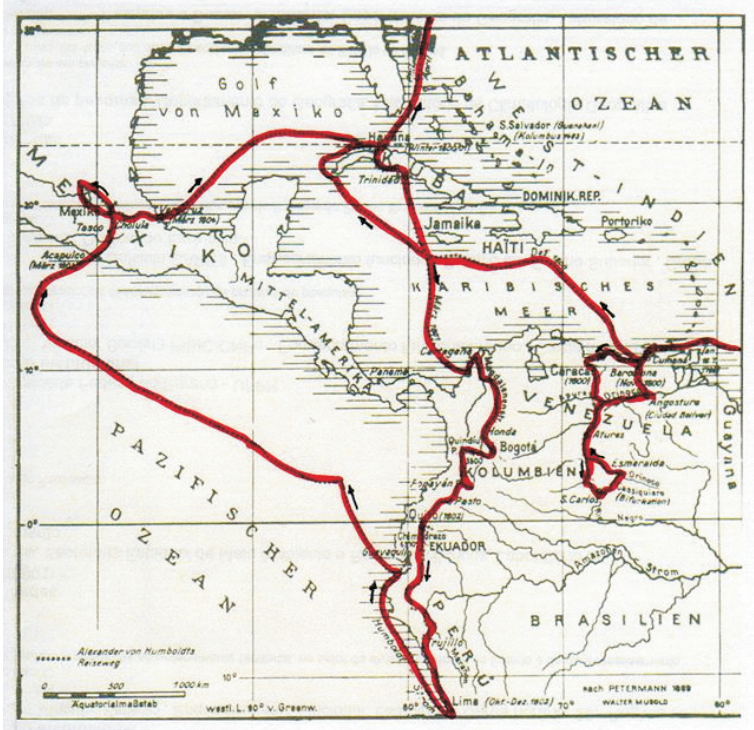

FIGURA 13 - EXPEDIÇÃO AO "NOVO MUNDO"

FONTE: Beck (1999), organizado por Springer (2009).

Para a época, os exploradores quebraram paradigmas da ciência com auxilio de procedimentos analíticos baseados em incontáveis medições e métodos para quantificar as observações. Determinação barométrica

16 Alexander von Humboldt e Aimé Bonpland sairam de La Coruña, na Espanha, em 5 de Junho de 1799, rumo às Canárias, e à Venezuela, onde aportaram na cidade de Cumaná em 16 de julho de 1799 (na época território pertencente à Espanha).

17 Segundo Gabaglia (1950) no Equador subiu o Chimborazo (5.800 metros), considerado até então como o pico mais alto dos Andes a que chegara qualquer viajante. No lombo de mula e com trajes sociais, percorreu os Andes coletando amostras geológicas, que segundo ele poderiam vir a comprovar o vulcanismo; fez observações astronômicas instalando observatórios e alcançou altitude superior a cinco mil e seiscentos metros.

18 Humboldt foi proibido pela coroa portuguesa de entrar em território brasileiro, não podendo assim, estudar a Bacia do rio Amazonas.

19 Raja Gabaglia escreveu o prefácio da edição portuguesa da obra “Quadros da Natureza”, vol. 01, editada em 1950.

20 Quadros da Natureza. 
SPRINGER, K. Considerações acerca da geografia de Alexander Von Humboldt...

da pressão do ar acima do nível do mar, temperatura, umidade, geomagnetismo, eletricidade do ar, e vários outros índices geofísicos e meteorológicos eram alguns dos índices observados e calculados por Humboldt e Bompland.

Apesar de muitas vezes a reputação de Humboldt estar associada à grande expedição realizada, mesmo antes desta viagem, ele já era um pesquisador famoso reconhecido mundialmente. Diferentemente dos naturalistas do século XVIII, Humboldt dá extrema impor-

\section{REFERÊNCIAS}

BECK, Hanno; SCHOENWALDT, Peter. O último dos grandes: Alexander von Humboldt. Inter Nationes: Bonn, 1999.

BORNHEIM, Gerd. Filosofia do romantismo. In: GUINSBURG, J. (Org.). O romantismo. 2. ed. São Paulo: Perspectiva, 1985.

CAPEL, Horácio. Filosofía y ciencia en la geografía contemporánea. Barcelona: Temas universitários, 1988.

FEISST, Werner. Alexander von Humboldt 1769 - 1859: das Bild seiner Zeit in 200 zeitgenössischen Stichen. 1978.

GABAGLIA, Raja. Prefácio. In: HUMBOLDT, Alexander von. Quadros da Natureza. Tradução de: Assis Carvalho. São Paulo: Ed. Brasileira, 1950. v. 1.

GÖETHE. Werther. Goethe werke. 10. ed. Munique: C. H. Beck Verlag, 1982.

Os sofrimentos do jovem Werther. Ediouro S. A. 1993.

GOMES, Álvaro Cardoso; VECHI, Carlos Alberto. A estética romântica: textos doutrinários. São Paulo: Atlas, 1992.

GOMES, Paulo César da Costa. Geografia e modernidade. Rio de Janeiro: Bertrand Brasil, 1996.

GUIMARÃES, Carlos Antonio Fragoso. O movimento romântico alemão. 1997. Disponível em: <http://www.geocities. com/Vienna/2809/roman.html>. Acesso em: 10/04/2007.

GUINSBURG, J. Romantismo, historicismo e história. In: 1985 (Org.). O romantismo. 2. ed. São Paulo: Perspectiva,

HAMPSON, Norman. O iluminismo. Lisboa: Ulisséia, 1973.

HORKHEIMER , M.; ADORNO, T. W. Dialektik der Aufldãrung - Philosophische Fragmente. Frankfurt/M. 1969.

HUMBOLDT, Alejandro de. Ensayo Politico sobre el Reyno de La Nueva - España. Tomo primero. Paris, 1882.

HUMBOLDT, Alexander von. Vom Orinoko zum Amazonas: Reize in die äquinoktial - gegenden des neuen kontinents. Wiesbaden: F. A. Brockhaus, 1958/1978. tância à meticulosa observação de fatores antrópicos, sendo também seu pensar cientifico e metodológico foi fortemente influenciado por Kant. Pertencente à classe nobre da época, Humboldt teve a oportunidade de tecer ampla rede de relações com cientistas, políticos e personalidades ilustres da vida intelectual e cultural. Entretanto, apesar de sua privilegiada posição social, em suas expedições assumia a personalidade de cientista, liberal, crítico e desprovido de preconceitos raciais e ou sociais.
Quadros da natureza. Trad. Assis Carvalho. São
Paulo: Ed. Brasileira, 1950a. v. 1.
$\begin{gathered}\text { Puadros da natureza. Trad. Assis Carvalho. São } \\ \text { Paulo: Ed. Brasileira, 1950b. v. } 2 .\end{gathered}$
. Cosmos: Ensayo de uma descripcion física del
mundo. Tomos I. Madrid (1851-1852). Córdoba, 2005a.
. Cosmos: Ensayo de uma descripcion física del

MENDONÇA, Francisco de Assis. Geografia e Meio Ambiente. 3. ed. São Paulo: Contexto, 1998.

MOISÉS. Massaud. História da literatura brasileira: romantismo, realismo. São Paulo: Cultrix, 1984.

MORAES, Antonio Carlos Robert de. A gênese da geografia moderna. 2. ed. São Paulo: Hucitec, 2002.

NUNES, Benedito. A visão romântica. In: GUINSBURG, J. (Org.). O romantismo. 2. ed. São Paulo: Perspectiva, 1985.

PALLARDÓ, F. Garrido. Los orígenes del romanticismo. Barcelona: Labor, 1968.

PAZ, Octavio. Os filhos do barro. Rio de Janeiro: Nova Fronteira, 1984.

PEREIRA, Raquel Maria Fontes. Da Geografia que se ensina da gênese da Geografia moderna. Florianopolis: Ed. da UFSC, 1999.

SAFRANSKI, Rüdiger. Romantik: Eine deutsche Affäre. München: Carl Hanser Verlag, 2007.

SCHELLING, Friedrich Wilhelm Joseph von. Filosofia da Arte. São Paulo: Ed. da USP, 2001.

VESENTINI, José Willian. Geografia, Natureza e Sociedade. São Paulo: Contexto, 1989.

VITTE, Antonio Carlos. Da metafísica da Natureza à gênese da Geografia Moderna. In: VITTE, Antonio Carlos (Org.). Contribuições à História e à Epistemologia da Geografia. Rio de Janeiro: Bertrand Brasil, 2007. 